FUTY Journal of the Environment, Vol. I No.1, July 2006

(c) School of Environmental Sciences, Federal University of Technology, Yola - Nigeria.. ISSN 1597-8826

\title{
ASSESSMENT OF ENVIRONMENTAL RADIOACTIVITY LEVELS IN JIMETA AREA OF METROPOLITAN YOLA, ADAMAWA STATE
}

\author{
Osita Meludu ${ }^{* 1}$, Emmanuel Odoh ${ }^{1}$ and Galtima Mala ${ }^{2}$ \\ ${ }^{1}$ Department of Physics, Federal University of Technology \\ P. M. B. 2076 Yola, Adamawa State \\ ${ }^{2}$ Department of Geography, Federal University of Technology \\ P. M. B. 2076 Yola, Adamawa State
}

\begin{abstract}
A radiological survey was carried out over Jimeta area of metropolitan Yola, Adamawa State, using a portable radiation alert monitor 4 of $S$. E. International, Inc. USA. The study showed that a mean whole body dose equivalent rate of $0.83 \pm$ $0.11 \mathrm{mSv} / \mathrm{y}$ and mean absorbed dose rate of $1.19 \pm 0.17 \mathrm{mGy} / \mathrm{y}$ resulted from total environmental radiation in Jimeta. Allowing for a cosmic radiation of $0.28 \mathrm{mGy} / \mathrm{y}$ the mean absorbed dose due to the environmental radioactivity is therefore 0.91 $m G y / y$. These values are lower than the $1 \mathrm{mSv} / \mathrm{y}$ recommended to the average individual member of the public by International Commission on Radiological Protection (ICRP). Hence residents of Jimeta are not unduly exposed to health risk due to environmental radiation exposure.
\end{abstract}

\section{Introduction}

Man's environment has two sources of ionizing radiation, natural and manmade. The natural radiation exposure arises mainly from the radioactive decay process of primordial radioactive elements and their decay products in the geological environment, and the presence of high energy gamma rays from the sun and outer space (cosmic rays). The level of the environmental radioactivity depends on the amount and distribution of the natural radionuclides such as ${ }^{238} \mathrm{U},{ }^{232} \mathrm{Th}$ and $40 \mathrm{~K}$ in that environment, the altitude and latitude of the location and the spacing of nuclear process industries ( NCRP, 1987).

In living tissues, the ionization of atoms by these radiations may lead to biological changes and some of these changes may result in adverse health effects (International Atomic Energy Agency, IAEA, 1987). These health effects may be somatic and/or genetic (Gonzalez, 1994).

In Nigeria, environmental radioactivity data are very scanty, with many regions having no data at all. Consequently this poses problems such as detecting areas of high environmental radioactivity levels in the country, studies of radiation related illness in such areas and control of industrial radioactive activities in the country.

The objective of this study is to assess the levels of environmental radioactivity in the Jimeta area of metropolitan Yola. Specifically the study will among, other things, ascertain if the radiation level is below the $1 \mathrm{mGy}$ which is the ICRP recommended dose limit for members of the public (ICRP, 1990). The study area, Jimeta encompasses Yola North and part of Yola South Local Council areas of Adamawa State, and is located in the North -Eastern axis of Nigeria. It is an urban settlement of about 350,000 people (National Population Commission 1991) and serves as the

* Corresponding Author 
FUTY Journal of the Environment, Vol. I No.1, July 2006

(c) School of Environmental Sciences, Federal University of Technology, Yola - Nigeria.. ISSN 1597-8826

political capital site of Adamawa State. The land area extends from Latitude $09.13^{\circ} \mathrm{N}$ and Longitude $12.6^{\circ} \mathrm{E}$ to Latitude $09.17^{\circ} \mathrm{N}$ and Longitude $12.9^{\circ} \mathrm{E}$. The map of the study area is given in figure 1 .

\section{Method}

A portable solid state Geiger-Mueller tube (Radiation Alert Monitor 4) manufactured by S. E. International, Inc. USA. was used to conduct in situ measurement of the Radiation dose equivalent levels in Jimeta area. The area was divided into 19 measurement sites, with a distance spacing of about $1.5 \mathrm{~km}$ (fig. 1). The spacing distance was selected to enhance effective coverage within the limit of available resources. An in situ radiation measurement was carried out at each of the sites in the month of February, 1999 and repeated in September, 2006. A solid state GM counter called radiation alert monitor 4 was used for the measurements. The environmental parameters for the month of February, 1999 were as follows: Mean maximum temperature, $38^{\circ} \mathrm{C}$; mean relative humidity $46 \%$ and mean average wind speed $5.1 \mathrm{~km} / \mathrm{hr}$, while in September, 2006 these parameters were Mean maximum temperature, $31^{\circ} \mathrm{C}$; mean relative humidity $70 \%$ and mean average wind speed 3.21 $\mathrm{km} / \mathrm{hr}$. The preference of in situ measurement to laboratory analysis is because the samples maintain their environmental characteristics (NCRP, 1987).The survey monitor was maintained at one meter above the ground level. At least two measurements were taken per site per day between 12 noon and $3.0 \mathrm{pm}$. This was repeated three other times on different days to take account of any fluctuation in environmental temperature. The monitor senses ionizing radiation by means of a GM (Geiger - Mueller) tube with a thin mica end window. The sensor is LND 712 halogen - quenched uncompensated GM tube with mica window $1.5-2.0 \mathrm{mg} / \mathrm{cm}^{2}$ thick. The tube is fully enclosed inside the instrument. The equipment was factory calibrated Approx. $1000 \mathrm{CPM} / \mathrm{mR} / \mathrm{hr}$ for cesium 137. The instrument provides a direct measurement of exposure rate in $\mathrm{mR} / \mathrm{h}$. The mean values of the exposure rate were converted to the absorbed dose rate by multiplying with 76 and a further multiplication with 0.7 resulted in the whole body equivalent dose rate (NCRP, 1987).

\section{Results and Discussions}

The radiation exposure levels, the absorbed dose and equivalent rates for the total environmental radiation in Jimeta are shown in Table 1 . The whole body dose equivalent rate ranged from $0.61 \mathrm{mSv} / \mathrm{y}$ to $1.03 \mathrm{mSv} / \mathrm{y}$ with an average value of 0.83 $\pm 0.11 \mathrm{mSv} / \mathrm{y}$. The mean whole body dose of $0.83 \pm 0.11 \mathrm{mSv} / \mathrm{y}$ is lower than the 1 $\mathrm{mSv} / \mathrm{y}$ recommended to the average individual member of the public (ICRP, 1990). The absorbed dose rate ranged from $0.87 \mathrm{mGy} / \mathrm{y}$ to $1.47 \mathrm{mGy} / \mathrm{y}$ with an average of $1.19 \pm 0.17 \mathrm{mGy} / \mathrm{y}$. The comparison of these results with values obtained in 2006 survey as (table 2) shows that the mean values absorbed dose rate, exposure rate and the wholebody equivalent dose rate has increased from 1.1852 to $1.1973 \mathrm{mGy} / \mathrm{y}$; 0.0156 to $0.0158 \mathrm{mR} / \mathrm{h} ; 0.8296$ to $0.8381 \mathrm{mSv} / \mathrm{y}$ respectively since 1999 Mean maximum temperature, $38^{\circ} \mathrm{C}$; mean relative humidity $46 \%$ and mean average wind speed $5.1 \mathrm{~km} / \mathrm{hr}$. These increases could be attributed to increase in human activities (viz; municipal wastes and automobile exhaust) during this period. However there were sites in which these quantities have decreased as shown in figure 1. This study covered both the dry and raining seasons as indicated by the environmental parameters for the measurement months and the results shows that the variation in 
FUTY Journal of the Environment, Vol. 1 No.1, July 2006

(c) School of Environmental Sciences, Federal University of Technology, Yola - Nigeria.. ISSN 1597-8826

the environmental parameters for these periods has not significantly affected radiation levels. The values obtained are much lower than the average equivalent dose rate of $45.22 \mathrm{mSv} / \mathrm{y}$ and average absorbed dose rate of $64.60 \mathrm{mGy} / \mathrm{y}$ resulting from total environmental radiation obtained by Uwah and Inyang (1998), for Calabar, which was very close to the permissible dose limit for uniform irradiation of the whole body set at $50 \mathrm{mSv} / \mathrm{y}$ for occupational exposure (ICRP,1990; Gonzalez, 1994). The value obtained in this study are in good agreement with the values of other studies (Kathren, 1984, 1985) which gave the mean annual exposure levels from natural radiation exposure to range from about $1.3 \mathrm{mSv}$ in the tropics to 2.2 $\mathrm{mSv}$ in the temperate zone. The values are also lower than the average annual effective dose equivalent of $2 \mathrm{mSv}$ from natural sources of radiation in areas of normal background (UNSCEAR 1982). Using the dose rate of $0.28 \mathrm{mGy} / \mathrm{y}$ (world average, UNSCEAR 1982), as the contribution of the ionizing component part of cosmic radiation, the mean absorbed dose due to the environmental radioactivity was obtained as $0.91 \mathrm{mGy} / \mathrm{y}$.

The low dose level experienced in Jimeta area could be due to low industrial activities in the area hence, there is little or no contribution to environmental radiation resulting from industrial pollution. The low level dose also indicates that the underlying soil/rock has low concentration of primordial radionuclides.

The findings of this study imply that residents of Jimeta are not unduly exposed to health risk resulting from environmental radiation exposure. Any illness traceable to radiation in the area might be due to other sources like medical, toxic chemical and heavy metals.

The area therefore provides a good baseline for assessing environmental radioactivity in the Country.

\section{References:}

Gonzales, A. J. (1994): Radiation Safety: New International Standard. International Atomic Energy Agency Bulletin, 36 (2).

ICRP (1990): Recommendations of the International Commission on Radiological protection: Annals of the ICRP, 194 (46) publication 60.

Kathren, Ronald L. (1984): Radioactivity in the Environment, Harwood Academic Publishers, New York;

Kathren, Ronald L. (1985): Radiation protection (Medical physics handbooks 16) Adam Hilger Ltd. Bristol U. K.

Mukherjee, R. and Mircheva, J. (1991): Radiobiological Effects of low-level Radiation and Cancer Risks. International Atomic Energy Agency Bulletin. 33 (2). pp 3235 .

NCRP (1987): Exposure of the Population in the United States and Canada from Natural Background Radiation. National Council on Radiation Protection and Measurements. NCRP Report No 94.

UNSCEAR (1982): United Nations Scientific Committee on the effects of Atomic Radiation, Ionizing Radiation: Sources and Biological effects. (New York UN, 1982). 
FUTY Journal of the Environment, Vol. I No.1, July 2006 (c) School of Environmental Sciences, Federal University of Technology, Yola - Nigeria.. ISSN 1597-8826

Uwah, E. J. and Inyang, S. O. (1998): Studies of environmental Radioactivity levels in Calabar. Global Journal of Pure and Applied Sciences vol. 4. No. 2.pp 187-190.

Table 1: Absorbed dose and Equivalent rates for total environmental radiation in Jimeta in 1999

\begin{tabular}{|c|c|c|c|c|}
\hline Location & $\begin{array}{l}\text { Site } \\
\text { No. }\end{array}$ & $\begin{array}{l}\text { Exposure rate } \\
(\mathrm{mR} / \mathrm{h})\end{array}$ & $\begin{array}{l}\text { Absorbed } \\
\text { dose } \\
\text { rate }(\mathrm{mGy} / \mathrm{y})\end{array}$ & $\begin{array}{l}\text { Whole body } \\
\text { Equivalent } \\
\text { dose rate }(\mathrm{mSv} / \mathrm{y})\end{array}$ \\
\hline Vinikilang & 1 & $\begin{array}{l}0.0155 \pm \\
0.0035\end{array}$ & $1.178 \pm 0.269$ & $0.825 \pm 0.188$ \\
\hline Mubi Rd/by pas Junction & 2 & $\begin{array}{l}0.0155 \pm \\
0.0021\end{array}$ & $1.178 \pm 0.161$ & $0.825 \pm 0.113$ \\
\hline Mubi round- about & 3 & $\begin{array}{l}0.0171 \pm \\
0.0004\end{array}$ & $\begin{array}{l}1.3 \pm \\
0.027\end{array}$ & $0.91 \pm 0.019$ \\
\hline Union bank round-about & 4 & $\begin{array}{l}0.0152 \pm \\
0.0021 \\
\end{array}$ & $1.155 \pm 0.161$ & $0.809 \pm 0.113$ \\
\hline Ribadu square & 5 & $\begin{array}{l}0.0115 \pm \\
0.0002 \\
\end{array}$ & $\begin{array}{l}0.874 \pm \\
0.018\end{array}$ & $0.612 \pm 0.013$ \\
\hline Govt. House Junction & 6 & $\begin{array}{l}0.0148 \pm \\
0.0\end{array}$ & $\begin{array}{l}1.125 \pm \\
0.00\end{array}$ & $0.787 \pm 0.0$ \\
\hline Police round-about & 7 & $\begin{array}{l}0.0129 \pm \\
0.0004\end{array}$ & $\begin{array}{l}0.98 \pm \\
0.027 \\
\end{array}$ & $0.686 \pm 0.019$ \\
\hline F. C. E & 8 & $\begin{array}{l}0.0179 \pm \\
0.0018\end{array}$ & $\begin{array}{l}1.36 \pm \\
0.134\end{array}$ & $0.952 \pm 0.094$ \\
\hline Jada st. Karewa & 9 & $\begin{array}{l}0.0126 \pm \\
0.0070\end{array}$ & $\begin{array}{l}0.958 \pm \\
0.528\end{array}$ & $0.67 \pm 0.370$ \\
\hline Karewa ext. & 10 & $\begin{array}{l}0.0183 \pm \\
0.0005\end{array}$ & $1.391 \pm 0.036$ & $0.974 \pm 0.025$ \\
\hline Bekaji Junc. & 11 & $\begin{array}{l}0.0153 \pm \\
0.0025\end{array}$ & $1.163 \pm 0.188$ & $0.814 \pm 0.132$ \\
\hline $\begin{array}{l}\text { Hospital Rd. by Gemba } \\
\text { Rd. }\end{array}$ & 12 & $\begin{array}{l}0.0174 \pm \\
0.0041 \\
\end{array}$ & $1.322 \pm 0.313$ & $0.926 \pm 0.219$ \\
\hline $\begin{array}{l}\text { Total Station Mustapha } \\
\text { way }\end{array}$ & 13 & $\begin{array}{l}0.013 \pm \\
0.0007\end{array}$ & $\begin{array}{l}0.988 \pm \\
0.054\end{array}$ & $0.692 \pm 0.038$ \\
\hline Lake gareio Junc. & 14 & $\begin{array}{l}0.0185 \pm \\
0.0021\end{array}$ & $1.406 \pm 0.161$ & $0.984 \pm 0.113$ \\
\hline PZ Junction & 15 & $\begin{array}{l}0.0152 \pm \\
0.0042\end{array}$ & $1.155 \pm 0.322$ & $0.809 \pm 0.226$ \\
\hline Royal Hospital & 16 & $\begin{array}{l}0.0145 \pm \\
0.0007 \\
\end{array}$ & $1.102 \pm 0.054$ & $0.771 \pm 0.038$ \\
\hline Kofore Rd. & 17 & $\begin{array}{l}0.0193 \pm \\
0.0040 \\
\end{array}$ & $1.467 \pm 0.307$ & $1.027 \pm 0.215$ \\
\hline Army barrack Rd. & 18 & $\begin{array}{l}0.0178 \pm \\
0.0013\end{array}$ & $1.353 \pm 0.101$ & $0.947 \pm 0.071$ \\
\hline Comm.Quts & 19 & $\begin{array}{l}0.014 \pm \\
0.0021\end{array}$ & $1.064 \pm 0.167$ & $0.745 \pm 0.117$ \\
\hline Mean & & $\begin{array}{l}0.0156 \pm \\
0.002\end{array}$ & $\begin{array}{l}1.185 \pm \\
0.170\end{array}$ & $0.830 \pm 0.119$ \\
\hline
\end{tabular}


FUTY Journal of the Environment, Vol. I No.1, July 2006

(c) School of Environmental Sciences, Federal University of Technology, Yola - Nigeria.. ISSN 1597-8826

Table 2: Comparison of Measurements taken in 1999 and 2006.

\begin{tabular}{|c|c|c|c|c|c|c|}
\hline \multirow[t]{2}{*}{ Site No } & \multicolumn{2}{|c|}{ Exposure rate $(\mathrm{mR} / \mathrm{h})$} & \multicolumn{2}{|c|}{$\begin{array}{l}\text { Absorbed dose rate } \\
(\mathrm{mGy} / \mathrm{y})\end{array}$} & \multicolumn{2}{|c|}{$\begin{array}{l}\text { Whole body } \\
\text { Equivalent } \\
\text { dose rate }(\mathrm{mSv} / \mathrm{y})\end{array}$} \\
\hline & 2006 & 1999 & 2006 & 1999 & 2006 & 1999 \\
\hline 01 & 0.01833333 & 0.0155 & 1.393333 & 1.178 & 0.975333 & 0.8246 \\
\hline 02 & 0.01833333 & 0.0155 & 1.393333 & 1.178 & 0.975333 & 0.8246 \\
\hline 03 & 0.01966667 & 0.0171 & 1.494667 & 1.2996 & 1.046267 & 0.90972 \\
\hline 04 & 0.019 & 0.0152 & 1.444 & 1.1552 & 1.0108 & 0.80864 \\
\hline 05 & 0.01133333 & 0.0115 & 0.861333 & 0.874 & 0.602933 & 0.6118 \\
\hline 06 & 0.012 & 0.0148 & 0.912 & 1.1248 & 0.6384 & 0.78736 \\
\hline 07 & 0.01633333 & 0.0129 & 1.241333 & 0.9804 & $\begin{array}{r}0.86893 \\
3\end{array}$ & 0.68628 \\
\hline 08 & 0.015 & 0.0179 & 1.14 & 1.3604 & 0.798 & 0.95228 \\
\hline 09 & 0.01366667 & 0.0126 & 1.038667 & 0.9576 & 0.727067 & 0.67032 \\
\hline 10 & 0.01333333 & 0.0183 & 1.013333 & 1.3908 & 0.709333 & 0.97356 \\
\hline 11 & 0.012 & 0.0153 & 0.912 & 1.1628 & 0.6384 & 0.81396 \\
\hline 12 & 0.01833333 & 0.0174 & 1.393333 & 1.3224 & 0.975333 & 0.92568 \\
\hline 13 & 0.014 & 0.013 & 1.064 & 0.988 & 0.7448 & 0.6916 \\
\hline 14 & 0.021 & 0.0185 & 1.596 & 1.406 & 1.1172 & 0.9842 \\
\hline 15 & 0.01733333 & 0.0152 & 1.317333 & 1.1552 & 0.922133 & 0.80864 \\
\hline 16 & 0.01333333 & 0.0145 & 1.013333 & 1.102 & 0.709333 & 0.7714 \\
\hline 17 & 0.016 & 0.0193 & 1.216 & 1.4668 & 0.8512 & 1.02676 \\
\hline 18 & 0.01533333 & 0.0178 & 1.165333 & 1.3528 & 0.815733 & 0.94696 \\
\hline 19 & 0.015 & 0.014 & 1.14 & 1.064 & 0.798 & 0.7448 \\
\hline Mean & 0.01575439 & 0.01559474 & 1.197333 & 1.1852 & 0.838133 & 0.82964 \\
\hline & & & & & & \\
\hline
\end{tabular}


FUTY Journal of the Environment, Vol. I No.1, July 2006

(c) School of Environmental Sciences, Federal University of Technology, Yola - Nigeria.. ISSN 1597-8826

Figure 2: Graph of the exposure rate in $\mathrm{mR} / \mathrm{h}$ for the various sites

\section{Comparison of Exposure rate in 1999 and 2006}

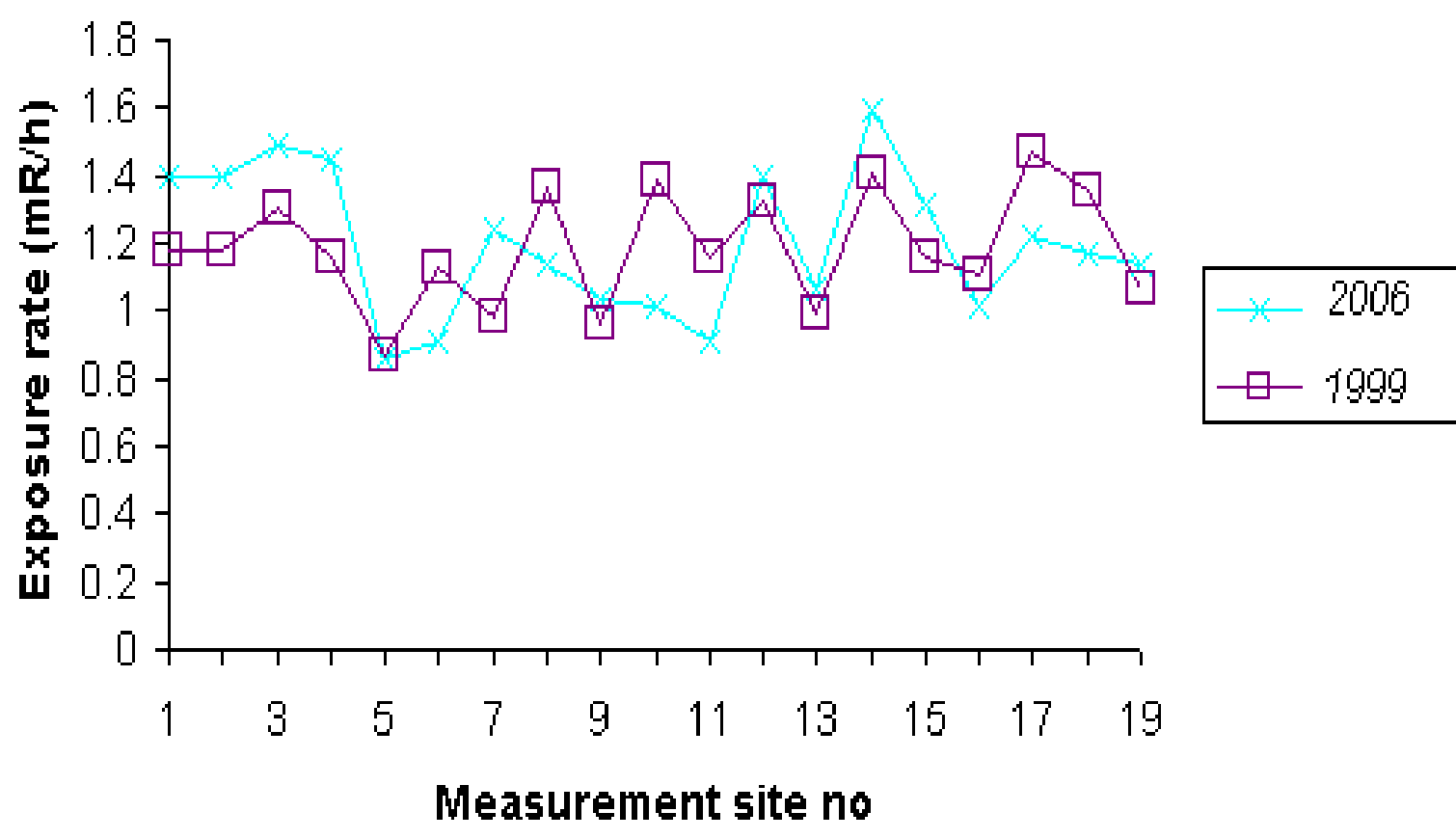

